\title{
The role of public sector libraries on enhancing public officers' quality service delivery in Ethiopia
}

\author{
Getachew Bayissa* and Lawrence Abraham Gojeh,*
}

\begin{abstract}
This paper reports part of a study of 2007, on the assessment of public sector libraries to enhance public officers' quality service delivery in Ethiopia. Most public officers of Ethiopia were found to have their highest qualification as first degree 125(51.4\%) and most library staffs had diploma in library science 14 (27.5\%). Most library staffs are in the lower level of the public service, who, mostly are not involved in policy decision-making of their organizations. Both public officers and library staffs indicated the types of library and information services provision in the public sector libraries to include; lending services 186(63.3\%) and reference and information service 169(57.5\%), while the least response was on abstracting service 24(8.2\%). Public officers on the other hand were satisfied with the type of library and information service provision in the public sector libraries of Ethiopia. The study concluded the Libraries in the Ethiopian public sector are inadequately equipped with professionally qualified library staff to meet the professional needs of users on the provisions of library and information services in the public libraries in Ethiopia. The library staffs are not trained, and the significance of libraries' roles are not satisfied by the users. The study advanced some recommendations and suggestions for further studies.
\end{abstract}

\section{INTRODUCTION}

The term public sector is used to mean the human resource organizations or agents of the government of a country, through which its functions and policies are executed. Microsoft Encarta (2009) referred to public sector as "government and its activities: the portion of a nation's affairs, especially economic affairs, that is controlled by government agencies". The public sector provides the public or citizens of a country with services to help meet their needs or wants, which include education, health, communication, etc. For example, the government of Ethiopia provides its public or citizens with services that are sometimes called public service or civil service through their public sectors like ministries, parastatals or agencies and the legislative arms of the government.

* Information Studies Department, Faculty of Natural and Information Science, Jimma University, P.O.Box 378, Jimma, Ethiopia

E-mail: Ghetachewbb@yahoo.com

E-mail:gojehla@yahoo.com 
The legislative arm of government refers to the offices of the President, Prime Minister, Deputy Prime Minister, House of Representatives, House of Federation, Council of Ministers of the Federal Democratic Republic of Ethiopia. While the terms public officers, public servants and civil servants are synonymously used in this paper to mean the people who work or are in the services of the public sectors of Ethiopia. Though library staffs or librarians are public officers but are here seen as providers of library and information services in the public sector libraries to enhance the general public officers' quality service delivery in Ethiopia.

These public sectors have libraries; established to support the public officers meet their information needs and the objectives of the organizations. Useni (1998:1) sees a library as being critical to the fortune of a nation. That it is a reservoir of knowledge containing a collection of data (information) required for meeting the varied needs of the users. The libraries perform roles that include the provision of library and information services that include careful selection, acquisition, organization, storage and dissemination of information materials in prints and non-print formats to meet and support the objectives and information needs of their users. Gojeh, (2004) defined a Library as where organised collections of information materials, in form of books and non- books materials with trained personnel, who manipulates the materials to provide library and information services to meet the information needs of their users. There are various types of libraries that depends on the type of organization or institution they find themselves. There are public, academic, schools, special, government/public sector libraries.

The library and information services; are provided by trained library staffs to satisfy and motivate users' information needs. Such services, span through lending, current awareness services, user education, literature searches, books exhibitions, indexing and abstracting services, photocopying services, internet services, binding services and computer services (Gojeh, 2004). However, not all library staffs are professional librarians. A professional librarian or librarian is one with a degree in the librarianship profession.

However, studies have seem to show that the magnitude of recognition for libraries and their roles are generally low, unsteady and in some cases considered an irrelevant arm of the public sector to attract government support in Ethiopia. Hence, the supports by the public sectors in Ethiopia to allow libraries perform their needed and significant roles merit greater emphases than has been hitherto.

Tadesse \& Bayou (2000) quoted Professor Girma Mullisa lamenting on the paucity of public libraries in Ethiopia and worse still in schools and colleges that made him to observe that:

"It should be the right of every citizen (in Ethiopia) to get access to centers of knowledge; as the primary repository of the story of man and the selfsacrifices, triumphs and failures. Libraries (or information centers), he said, have an essential role to play, that we are indeed entering a century of Information Technology (IT), the world is truly becoming a global village, through IT; and one of its many offshoots is the Internet. For anybody to be denied access to centers of knowledge is tantamount to being left out of that global village and thrown into the cold. In the harsh competitive world of today and tomorrow, this is no less than committing suicide".

The remark goes to stress the role of libraries at this time of information technology and globalization, where organs of the civil service may have the financial resources to carry out the strategic planning and management of the Civil Service structure; but without enough pre-requisite 
information for decision-making, may as well fail.

Two Government policy documents in Ethiopia- Education and Training Policy (1994) and Education Sector Strategy (1994), discussed Ethiopia Educational policies and its strategies of achievements of its goals but surprisingly, these documents did not reflect libraries or information centers and librarians as an advert necessity and supporters for successful education at all levels in Ethiopia. Related to this, is the education of librarians and information managers as vital means for furthering the educational programmes of the citizens; after and during schooling for both students and staff and for the rural communities that do not have the opportunity for formal education, as well as the education of professional librarians in library schools to work in the libraries or information centers in the public sector of Ethiopia.

\section{Statement of the problem}

For any successful planning at the three tiers of Government in Ethiopia (i.e. Federal, Region and Woreda levels), the public officers need information, which is vital for the execution of Government functions and for meeting its set vision, mission and objectives. Library and information services suffer far more than other associated support public sectors' services or operations that consequently, their outputs hardly meet the information needs of the public sectors' civil servants. Hence, the question arose as to what extent are libraries in the public sector of Ethiopia are able to meet their roles of providing library and information services to meet the information needs of public officers to enhance their quality service delivery in the public sectors of Ethiopia?

It is the intention of this article to report an aspect of a study conducted in 2007 on the assessment of library and information services to enhance quality service delivery in the public sector of Ethiopia. The following research questions were addressed in this study:

1. What are the highest qualifications of the public officers with special reference to library staffs in the public sector libraries in Ethiopia?

2. What types of library and information services are provided in the public sector libraries/information centers in Ethiopia as indicated by the public officers and library staffs?

3. What are the levels of satisfaction with library and information services provided in the public sector libraries/information center as indicated by the public officers in Ethiopia?

\section{Objective of the Research}

The broad objective of the study was to assess the roles of public sector libraries/information centers on enhancing public officers' quality service delivery in Ethiopia. The specific objectives of the study were to:

1. Establish the highest qualifications of public officers with special reference to library staffs in the public sector libraries in Ethiopia.

2. Identify the types of library and information services the public sector libraries or information centers provide for their users.

3. Find out the levels of satisfaction with library and information services of public officers in the public sector libraries or information centers in Ethiopia.

\section{METHODOLOGY \\ Design and Sample}

A cross-sectional survey method was used for the study. While a multistage-stratifiedrandom sampling and proportional sampling techniques were used to draw the sample population of public sectors and subjects. The study therefore drew three research samples as follows: Research sample one was 15 arms of the public sectors that were: 1 legislative arm of government, 9 ministries and 5 agencies/parastatals, drawn from the 57 arms of the public sector of 
Ethiopia that were categorised into 6 legislative arms of government, 20 ministries and 31 agencies/parastatals respectively. The categorisation was performed before drawing the sample.

Research sample two was 243 public officers and research sample three was 51 library staff. Samples two and three were drawn from the civil servants of the 15 public sectors with head offices in Addis Ababa. To settle for the sample sizes of the study, the researchers considered the geographical spread of the public sector in Ethiopia; the population of the public officers in the public sectors and their ranks (i.e., top, middle and lower level).

\section{Data Collection}

In line with the objectives and nature of the survey, a face-to-face data collection was carried out using two sets of questionnaires to collect information from public officers and library staff respectively. Documentary sources or records were observed from circulation desks of libraries and library officers' tables' in-charge of the relevant documents. Interviews and discussions were conducted with some library staff in-charge and some public officers in cases where completed questionnaire could not satisfy researchers' and needed verification on the items. The face-to-face questionnaire distribution to respondents, the interview and the observation of documents were based on the research questions. However, to have the respondents involved in the study, a letter of permission was sent to all public sectors involved in the study.

The Public officers' questionnaire was divided into two sections. Section one was on personal information of the respondents and five items. Section two was on services and had 21 items. The second questionnaire was for library staffs; who were also public officers but providers of library and information services. The questionnaire was divided into two sections. Section one was on personal information of respondents and had five items. Section two was on services to users and had 21 items.
In order to arrive at the data analysis, various quality control mechanisms were applied on the different stages of the survey activities. There were theoretical (classroom) as well as practical training of the field staffs; others include administration of the questionnaires, interviews, preparing detailed and clear editing and coding instruction manual for editing and verifying the data collected.

The completed questionnaires were manually edited and coded. Verification was done before the computer data entry and editing as well. The Statistical Package for the Social Sciences (SPSS), for windows 12.0 programming system was used for the data analysis. Frequencies and percentages were the statistics used to highlight some of the variables under study.

\section{RESULTS}

\section{Response rate}

Of the 15(100\%) public sectors of Ethiopia (i.e one legislative arm, 9 ministries and 5 agencies/parastatals) involved in the study; only $11(73.3 \%)$ had a library in its organization. From discussions, interviews and observations of documents in the public sector libraries, the respondents referred to their organizations as having a "library" and not an "information center". This therefore implies that the term "library" is strongly supported as a nomenclature in the civil service of Ethiopia as opposed to the use of "information center". However, in recognition of this finding, our discussions will henceforth use "library/libraries" instead of a combination "library/libraries or information centers” to express opinion about the library of the public sectors.

\section{Public officers}

Personal information was asked of the public officers in the public sector of Ethiopia that include: gender, rank, highest qualification and working experience.

Of the $243(100 \%)$ public officers, who responded to the questionnaire, a proportion of $176(72.4 \%)$ were male, while $42(17.3 \%)$ 
were female and 25(10.3\%) did not respond to the item. From a total of 51 (100\%) library staffs, who responded to the questionnaire, a proportion of 22 (43.1\%) were male, while 16 (31.4\%) were female and 13 (25.5\%) did not respond to the item. From the response rate of public officers and library staffs respectively, we may conclude that most respondents were male, an indication that most public servants of Ethiopia were male as at 2007; the time the study was conducted.

The public officers that responded to the questionnaire were categorized into three distinct categories (i.e. top, middle and lower level public officers). The highest respondents were middle level public officers, with 141(58\%) respondents, the least response was the lower level public officers with 23(9.5\%) and 24(9.9\%) did not respond to the item. In the same manner, library staffs were categorized into top, middle and lower level public officers. Of the 51(100\%) library staffs that responded; the highest proportional respondents of $19(37.3 \%)$ were in the lower level and the least response of 5(9.8\%) was in the top level category, while the remaining $13(25.4 \%)$ did not indicate their ranks.

The highest qualifications of respondents were investigated. Of the public officers respondents, 125(51.4\%) had first degree, the least response was "others" (which was other qualifications being Grade 10 level of education) and Ph.D was 1 (.4\%) and
24(10.0\%) did not respond to the item. Of the Library staffs' respondents, 14 (27.5\%) had diploma in library study, the least response was "others" (which was other qualifications being Grade 8, and 10 levels of education) that was $5(9.7 \%)$ and $14(27.5 \%)$ did not respond to the item.

The working experience of public officers' respondents was an interesting variable for noting by the researchers. It was then noted that of the $243(100 \%)$ respondents on the item, 53 (21.8\%) of the public officers had the highest working experience in the range of 15-20 years and the least working experience was 30 years, with 9(3.7\%) respondents. While 33 (13.6\%) did not indicate their level of working experience. On the contrary, the highest respondents $11(21.6 \%)$ of the library staffs had worked for less than 5 years, the least response was 1 (2\%) and had working experience in the range 25-30 years, this could be reflective of the very low qualified and low top level library staff in the Ethiopian public service.

\section{Types of library and information services} provided in the public sector libraries

Public officers and library staffs were requested in their respective questionnaires to indicate from a list of 21 options of the types of library and information services that were provided in the public sector libraries. Table 1 shows public officers and library staffs' responses classified according to types of library and information services provided by the public sector libraries. 
Table 1: Public officers and library staffs respondents classified according to types of library and information services

\begin{tabular}{|c|c|c|c|}
\hline \multirow{2}{*}{$\begin{array}{l}\text { S/n Types of Library and information } \\
\text { services provided by public sector } \\
\text { libraries. }\end{array}$} & \multicolumn{3}{|c|}{ Respondents } \\
\hline & Groups & S.T & G.T \\
\hline \multirow[t]{2}{*}{ 1. lending services } & $\mathrm{PO}$ & $158(65.0 \%$ & $186(63.3 \%)$ \\
\hline & LBS & $28(54.9 \%)$ & \\
\hline \multirow[t]{2}{*}{ 2. Computer services } & $\mathrm{PO}$ & $71(29.2 \%)$ & $91(31.0 \%)$ \\
\hline & LBS & $20(39.2 \%)$ & \\
\hline \multirow[t]{2}{*}{ 3. Inter-library loan services } & $\mathrm{PO}$ & $67(27.6 \%)$ & $83(28.2 \%)$ \\
\hline & LBS & $16(31.4 \%)$ & \\
\hline \multirow[t]{2}{*}{ 4. Reference and information services } & $\mathrm{PO}$ & $135(55.6 \%)$ & $169(57.5 \%)$ \\
\hline & LBS & $34(66.7 \%)$ & \\
\hline \multirow[t]{2}{*}{ 5. Current awareness services } & $\mathrm{PO}$ & $75(30.9 \%)$ & $91(31.0 \%)$ \\
\hline & LBS & $16(31.4 \%)$ & \\
\hline \multirow[t]{2}{*}{$\begin{array}{l}\text { 6.SelectiveDissemination } \\
\text { of information }\end{array}$} & PO & $40(16.5 \%)$ & $46(15.6 \%)$ \\
\hline & LBS & $6(11.8 \%)$ & \\
\hline \multirow[t]{2}{*}{ 7. User-Education } & $\mathrm{PO}$ & $37(15.2 \%)$ & $45(15.3 \%)$ \\
\hline & LBS & $8(15.7 \%)$ & \\
\hline \multirow[t]{2}{*}{ 8. Literature searching } & $\mathrm{PO}$ & $58(23.9 \%)$ & $74(25.2 \%)$ \\
\hline & LBS & $16(31.4 \%)$ & \\
\hline \multirow[t]{2}{*}{ 9. Bibliographical services } & $\mathrm{PO}$ & $33(13.6 \%)$ & $44(15.0 \%)$ \\
\hline & LBS & $11(21.6 \%)$ & \\
\hline \multirow[t]{2}{*}{ 10. Indexing services } & $\mathrm{PO}$ & $26(107 \%)$ & $31(10.5 \%)$ \\
\hline & LBS & $5(9.8 \%)$ & \\
\hline \multirow[t]{2}{*}{ 11. Abstracting services } & $\mathrm{PO}$ & $19(7.8 \%)$ & $24(8.2 \%)$ \\
\hline & LBS & $5(9.8 \%)$ & \\
\hline \multirow[t]{2}{*}{ 12. Photocopying services } & $\mathrm{PO}$ & $42(17.3 \%)$ & $54(18.4 \%)$ \\
\hline & LBS & $12(45.1 \%)$ & \\
\hline \multirow[t]{2}{*}{ 13. Binding services } & $\mathrm{PO}$ & $33(13.6 \%)$ & $44(! 5.0 \%)$ \\
\hline & LBS & $11(21.6)$ & \\
\hline \multirow[t]{2}{*}{ 14. Audio-Visual services } & $\mathrm{PO}$ & $32(13.2 \%)$ & $48(16.3 \%)$ \\
\hline & LBS & $16(31.4 \%)$ & \\
\hline \multirow[t]{2}{*}{ 15. Internet literature searching } & $\mathrm{PO}$ & $40(16.5 \%)$ & $56(19.0 \%)$ \\
\hline & LBS & $16(31.4 \%)$ & \\
\hline \multirow[t]{2}{*}{ 16. CD-ROM services } & $\mathrm{PO}$ & $44(18.1 \%)$ & $57(19.4 \%)$ \\
\hline & LBS & $13(25.5 \%)$ & \\
\hline \multirow[t]{2}{*}{ 17. Exhibition/display services } & $\mathrm{PO}$ & $23(9.5 \%)$ & $37(12.6 \%)$ \\
\hline & LBS & $14(27.5 \%)$ & \\
\hline \multirow[t]{2}{*}{ 18. E-mail services } & $\mathrm{PO}$ & $47(19.3 \%)$ & $63(21.4 \%)$ \\
\hline & LBS & $16(31.4 \%)$ & \\
\hline \multirow[t]{2}{*}{ 19. Security of users' property } & $\mathrm{PO}$ & 33(13.6\%) & $49(16.7 \%)$ \\
\hline & LBS & $16(31.4 \%)$ & \\
\hline
\end{tabular}




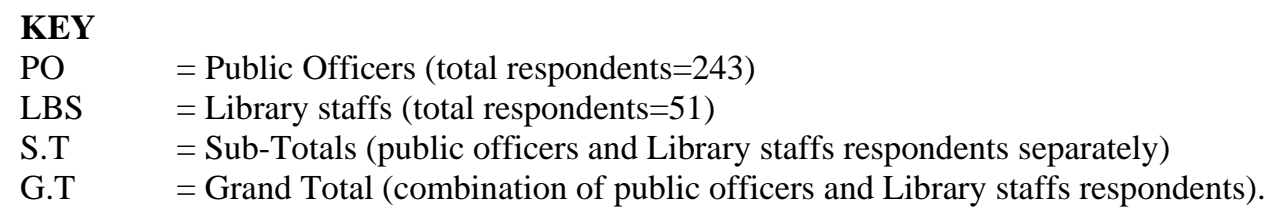

The table 1 shows that, of the 294 (100\%) respondents of both public officers and library staffs; most respondents indicated the types of library and information services provision to include: lending services 186(63.3\%) and reference and information service 169(57.5\%), while the least response was on abstracting service $24(8.2 \%)$.

An item analysis on the public officers' response on the same table 1 shows that the following types of library and information services were provided in the public sector libraries and they were: lending services 158(65.0\%), reference and information service $135(55.6 \%)$ and the least response was on abstracting service $19(7.8 \%)$. But the library staffs' response on the item analysis on the same table 1 , shows an agreement on the highest response on lending services 28(54.9\%), reference and information service $34(66.7 \%)$ and the least response was on abstracting service 3(9.8\%). Although, the library staffs' response showed another least response of the services on indexes 3(9.8\%).

\section{Level of satisfaction of public officers on types of library and information services provision}

From the list of 21 different options on types of library and information services provision in the public sector libraries, respondents were requested in table 2 below to indicate on each service; their levels of satisfaction. 
Table 2: Public officers responses on each types of library and information services provision classified according to levels of satisfaction

\begin{tabular}{|c|c|c|c|c|c|c|c|c|}
\hline \multirow[t]{2}{*}{ ITEMS LIS provision } & \multicolumn{2}{|c|}{ Levels of satisfaction } & \multirow[b]{2}{*}{ DS } & \multirow[b]{2}{*}{ HD } & \multirow[t]{2}{*}{ ER } & \multirow[t]{2}{*}{$\mathbf{A R}$} & \multirow{2}{*}{\multicolumn{2}{|c|}{ Decision }} \\
\hline & HS & $\mathrm{S}$ & & & & & & \\
\hline 1. Lending services & $7(2.9 \%)$ & $26(10.7 \%)$ & $77(31.7 \%)$ & $49(20.2 \%)$ & $243(100 \%)$ & $159(64.5 \%)$ & $126(51.3 \%)$ & \\
\hline 2. Computer service & $27(11.1 \%)$ & $36(14.8 \%)$ & $42(17.3 \%)$ & $25(10.3 \%)$ & $243(100 \%)$ & $130(53.5 \%)$ & $67(27.6 \%)$ & DS \\
\hline 3. Inter-library loan services & $17(7.0 \%)$ & $26(10.7 \%)$ & $52(21.4 \%)$ & $15(6.2 \%)$ & $243(100 \%)$ & $110(45.3 \%)$ & $67(27.6 \%)$ & DS \\
\hline $\begin{array}{l}\text { 4. Reference and information } \\
\text { services }\end{array}$ & $11(4.5 \%)$ & $35(14.4 \%)$ & $85(35.0)$ & $27(11.1 \%)$ & $243(100 \%)$ & $158(65.0 \%)$ & $112(46.1 \%)$ & \\
\hline 5. Current awareness services & $9(3.7 \%)$ & $37(15.2 \%)$ & $57(23.5 \%)$ & $17(7.0 \%)$ & $243(100 \%)$ & $120(49.4 \%)$ & $74(30.5 \%)$ & DS \\
\hline 6. Selective Dissemination of & & & & & & & & \\
\hline information & $22(9.1 \%)$ & $30(12.3 \%)$ & $36(14.8 \%)$ & $6(2.5 \%)$ & $243(100 \%)$ & 94(38.7\%) & $52(21.4 \%)$ & $\mathbf{S}$ \\
\hline 7. User- Education & $17(7.0 \%)$ & $30(12.3 \%)$ & $33(13.6 \%)$ & $6(2.5 \%)$ & $243(100 \%)$ & $86(35.4 \%)$ & $47(19.3 \%)$ & $\mathrm{S}$ \\
\hline 8. Literature searching & $19(7.8 \%)$ & $35(14.4 \%)$ & $53(21.8 \%)$ & $8(3.3 \%)$ & $243(100 \%)$ & $115(47.3 \%)$ & $61(25.1 \%)$ & DS \\
\hline 9. Bibliographical services & $17(7.0 \%)$ & $35(14.4 \%)$ & $37(15.2 \%)$ & $3(1.2 \%)$ & $243(100 \%)$ & $92(37.9 \%)$ & $52(21.4 \%)$ & $\mathrm{S}$ \\
\hline 10. Indexing services & $12(4.9 \%)$ & $35(14.4 \%)$ & $25(10.3 \%)$ & $4(1.6 \%)$ & $243(100 \%)$ & $76(32.1 \%)$ & $47(19.3 \%)$ & $\mathrm{S}$ \\
\hline 11. Abstracting services & $16(6.6 \%)$ & $36(14.8 \%)$ & $16(6.6 \%)$ & 1.(.4\%) & $243(100 \%)$ & $69(28,4 \%)$ & $52(21.4 \%)$ & $\mathbf{S}$ \\
\hline 12. Photocopying services & $14(5.8 \%)$ & $21(8.6 \%)$ & $19(7.8 \%)$ & $11(4.5 \%)$ & $243(100 \%)$ & $65(26.7 \%)$ & $35(14.4 \%)$ & $\mathrm{S}$ \\
\hline 13. Binding services & $20(8.2 \%)$ & $34(14.0 \%)$ & $16(6.6 \%)$ & $9(3.7 \%)$ & $243(100 \%)$ & $79(32.5 \%)$ & $54(22.2 \%)$ & $\mathrm{S}$ \\
\hline 14. Audio-visual services & $26(10.7 \%)$ & $36(14.8 \%)$ & $10(4.1 \%)$ & $6(2.5 \%)$ & $243(100 \%)$ & 78(32.1\%) & $62(25.5 \%)$ & $\mathbf{S}$ \\
\hline 15. Internet literature searching & $25(10.3 \%)$ & $29(11.9 \%)$ & $33(13.6 \%)$ & $11(4.5 \%)$ & $243(100 \%)$ & $98(40.3 \%)$ & $54(22.2 \%)$ & $\mathbf{S}$ \\
\hline 16. CD-ROM services & $26(10.7 \%)$ & $38(15.6 \%)$ & $19(7.8 \%)$ & $6(2.5 \%)$ & $243(100 \%)$ & $89(36.6 \%)$ & $64(26.3 \%)$ & $\mathrm{s}$ \\
\hline 17. Exhibition/display services & $20(8.2 \%)$ & $36(14.8 \%)$ & $19(7.8 \%)$ & $5(2.1 \%)$ & $243(100 \%)$ & $80(32.9 \%)$ & $56(23.0 \%)$ & $\mathbf{S}$ \\
\hline 18. E-mail services & $25(10.3 \%)$ & $35(14.4 \%)$ & $30(12.3 \%)$ & $13(5.3 \%)$ & $243(100 \%)$ & $103(42.4 \%)$ & $60(24.7 \%)$ & $\mathbf{S}$ \\
\hline 19. Security of users' property & $16(6.6 \%)$ & $31(12.8 \%)$ & $30(12.3 \%)$ & $8(3.3 \%)$ & $243(100 \%)$ & $85(35.0 \%)$ & & \\
\hline $47(19.4 \%) \quad \mathrm{S}$ & & & & & & & & \\
\hline $\begin{array}{l}\text { 20. Information and reservation } \\
\text { services }\end{array}$ & $9(3.7 \%)$ & $54(22.2 \%)$ & $32(13 . .2$ & $10(4.1 \%)$ & $243(100 \%)$ & $65(26.7 \%)$ & $63(25.9 \%)$ & $\mathbf{S}$ \\
\hline 21. Others & $4(1.6 \%)$ & $32(13.2 \%)$ & $4(1.6 \%)$ & - & $243(100 \%)$ & $40(16.5 \%)$ & $36(14.8 \%)$ & $\mathrm{s}$ \\
\hline TOTAL & $359(18.1 \%)$ & 672(33.8\%) & $725(36.5 \%)$ & $231(11.6 \%)$ & $5103(100 \%)$ & 1987(38.9\%) & $1288(100 \%$ & \\
\hline
\end{tabular}

KEY

KEY

$\mathrm{ER}=$ Expected responses 5103(100\%) $\quad$ HS $=\quad$ Highly Satisfied $\mathrm{S}=\quad$ Satisfied
DS $=\quad$ Dissatisfied

$\mathrm{HD}=\quad$ Highly Dissatisfied 
Table 2 above shows a proportional analysis on the levels of satisfactions of public officers on each type of services provided by public sector libraries. The result shows that, of the $243(100 \%)$ respondents on each item of services, public officers were highly satisfied with computer services 27(11.1\%), they were satisfied with information and reservation services 54 (22.2\%), dissatisfied with reference and information services 85 (35.0\%) and highly dissatisfied with lending services 49 (20.2\%).

On item analysis, the public officers were satisfied with 16 items of library and information services (i.e. items 6, 7, 9-21 or $60.6 \%)$. They were however; dissatisfied with 6 items (i.e. items 1-5 \& 8 or $39.4 \%)$. The public officers were generally satisfied (60.6\%) with their public sector library and information services provision in Ethiopia.

Although, of the total expected responses of $5103(100 \%)$ on all the 21 items of the types of library and information services, only 1987 (38.9\%) responses was made by the public officers. This revealed that about 3116 (61.1\%) did not actually response to at least one item of the types of library and information services provision in the public sector libraries. Table 2 above shows that only item one of the services that 159 (51. 3\%) responses were made from a total respondents of 243 (100\%).

\section{Discussions}

The results of the study confirmed the types of library and information services provision in the public sector libraries to include; lending services 186(63.3\%) and reference and information service 169(57.5\%), while abstracting service $24(8.2 \%)$ is recognized as the least type of library and information service. From the result of the analysis, we can conclude that the public sector libraries are handicap in the provision of aggressive and varying types of acceptable library and information services for its enthusiastic users. This also may not be far from the caliber of staffs working in the libraries, who are likely not professionals or qualified library staffs.

Though the study confirmed that most public officers of Ethiopia are professionally qualified, with their highest qualification as first degree 125 (51.4\%); a situation that would warrant for quality service delivery if provided with effective and efficient library and information services from qualified library staffs. But the reverse is the case in the public sector libraries, where the study revealed that most library staffs' highest qualification was diploma in library science 14 (27.5\%). The situation does not make them professionals but "para-professionals". Though they may head the public sector libraries but are limited by professional capacity. The implication of most library staffs in the public service was that they are in the lower level of the public service, who, mostly are not involved in policy decision-making of their organizations. This finding is supported by other studies that found employees' perceptions and valuations of the environment mediating on attitudinal and behavioural responses (James and Jones, 1974). The finding therefore, demonstrated that when people are professionally qualified in a work environment, the better their interaction with colleagues with professional qualifications in other disciplines working in the same environment.

The study further revealed that public officers were generally satisfied with the overall types of library and information services provision in the public sector libraries but surprisingly on Table I, where lending services and reference and information services are said to be the types of library and information services provided; the same services on Table 2 
are said to be dissatisfied by the public officers on their levels of satisfaction. The implication of this observation lies on the fact that the more accessible users are to library and information services, the more likely they will be used but the theory did not hold in this respect. However, Table 2 further revealed that of 5103 (100\%) respondents only 1987 (38.9\%) responses were made on the levels of satisfaction on the 21 items of library and information services. The situation, could mean that majority of the public officers could not have such services in their public sector libraries, hence, could not reflect their opinions.

However, the result of general satisfaction on the services tends to attest that the more accessible users are to library materials, the more likely they will be used (Allen; 1968 and Rosenberg; 1967). Readers in libraries tend to select types of library and information services on the basis of the efforts they are likely to expend in order to use. This was validated in the study of Aguolu (1985). The proximity to the relevant collections, ease of access to them and the more personalized services based upon proper identification individual information needs; are often the dominant services of special libraries. Public sector libraries all over the world are special libraries that were established to serve specific needs mainly for the personnel of the parent organizations.

\section{Conclusions and Recommendations}

The study concludes that most public officers in the public sectors of Ethiopia have first degree as their highest qualification but their counterparts in the public sector libraries have diploma as their highest qualification. It also conclude that although the public officers were generally satisfied with the types of library and information services provision, the services were found to be professionally inadequate to enhance public officers' quality service delivery in their organizations. The reason being; that most of the library staffs were not professionally qualified, to provide the types of library and information services to meet the roles of the public sector libraries in Ethiopia. Hence, the following recommendations are advanced:

1. The policy makers in the public sector of Ethiopia should consider the recruitment of experienced and professionally qualified library and information science professionals into the public sector libraries for efficient and effective library and information services.

2. In order to remain relevant in the scheme of professional discharge of library functions, library staffs in public sector libraries should pay particular and greater attention to user studies, information needs of users, the capturing of data, creation of databases and provision of internet connectivity, binding equipment, photocopiers, and computers; and engaging in dynamic indexing and abstracting services, compilation of bibliographies, CDROM packages selective dissemination of information and current awareness services.

3. The Information Science department in Jimma University, Ethiopia; should widen its training programmes to include Distance learning students; where library staff in public sector libraries should acquire professional qualifications for quality service in their organizations.

7. The Federal Ministry of Culture and Tourism should consider separating the National Archives and Library Agency established under the Proclamation no. 179/1999 into autonomous agencies as: "National Archives of Ethiopia" and "National Library of Ethiopia" with separate Director Generals for the efficient and effective performance of the functions of the Agencies. 
Suggestions for Further Study

From the findings and conclusions above, the following suggestions are made for further investigations:

1. The effect of the professional training programme of Jimma University Information Science on the quality and quantity of professionals in the public sector libraries of Ethiopia should be made.

\section{ACKNOWLEDGEMENT}

We express our profound gratitude to the President of Jimma University and his management team for considering and approving the sponsorship of this research activities. We also register our profound gratitude to the Publication and Research Committee of the Faculty of Natural and Information Science for its consideration, encouragement and support for the study. Nonetheless, we cannot otherwise but be most grateful to the than Dean (Ato Dawit Kefle) of the Natural and Information Science for his un-quantified support for the study.

We specially thank all the Human Resource Departments of all the public service organizations in Ethiopia. This includes the legislative arms, ministries and agencies involved in the study, for their deserved cooperation and assistance during the collection of data and for their encouragement through out the study.

\section{REFERENCES}

Agualu, C.C (1985). Centralization and decentralization in African University libraries: a theoretical, critical reexamination. International library movement, 7(4): 157-172.

Allen, T.J. (1968). Organizational aspects of information flow and technology. ASLIB proceedings, $\mathrm{xx}$ (November): 433-454.

Blagden,J. (1988). Some thoughts on use and users. Iatul Quaterly 2(3), p. $125-134$.
Central Statistical Authority (1999).

Statistical report on the 1999

National Labour force survey. Addis Ababa: The Federal Democratic Republic of Ethiopia.

Education and Training policy. (1994). Addis Ababa: Federal Democratic Republic of Ethiopia.

Education Sector Strategy. (1994). Addis Ababa: Transitional Government of Ethiopia.

Federal Democratic Republic of Ethiopia (1976: E.C). Legal notice no, 40/1976 the Ethiopian National Archives and Library. Ethiopia: FDRE

Federal Democratic Republic of Ethiopia (1976: E.C). Proclamation no, 50/1976 the Ethiopian National Archives and Library Proclamation. Ethiopia: FDRE

Federal Democratic Republic of Ethiopia (1999: E.C). Proclamation no, 179/1999 the Ethiopian National Archives and Library Proclamation. Ethiopia: FDRE

Gessesse, K. (2000). Collection development and management in the twenty-first

Century with special reference to academic libraries: an overview. Library management, 21(7): 365372.

Gojeh, L.A. (2004). An Assessment of users' motivation and satisfaction with library

and information services in Colleges of Education in Nigeria. An unpublished Ph.D Thesis submitted to Ahmadu Bello University,Zaria.

Griffin, Mary (1980). Putting a price on information: practice illustrating a basic principle. Aslib Proceedings, 42 (1), p. 26-34.

James, L.R. \& Jones, A.P. (1974). Organization Climate: A Review of Theory and Research.

Psychological Bulletin, 81: 10961112.

Jimma University. (2007). Dairy. Jimma, Ethiopia: 
Line,Maurice B. (1974). Information and library needs, wants, demands and uses. Draft definitions, 1(2), p.87.

Microsoft Encarta. (2009). Public Sector. 1993-2008 Microsoft Corporation.

Microsoft Encarta. (2007). 1993-2006 Microsoft Corporation.

Odusanwo, G.O. (1999). Essential knowledge-base for Government libraries in a

democratic culture. In (NLA Compendium of paper presentations): Information for the sustenance of a democratic culture. Port-Harcourt, Nigeria: NLA

Rosenberg, V. (1967). Factors affecting the preferences of industrial personnel for

information gathering methods, Information storage and retrieval Journal, 111(July): 119-127.
Smith, B.B. (1983). Marketing Strategies for Libraries. Library Management, 4(1), p. 1-52

Tadesse, Neguissie \& Bayou, Abiyot. (2000). Interview with Professor

Girma Mullisa. (In). Addis Ababa University Libraries in Perspective: $5^{\text {th }}$ years Golden Jubilee Aniversary. Addis Ababa: AAUL. Pp.15-19.

Taylor, R.S. (1986). Valued-added process in information systems.

Ablex Publishing Corporation.

Uche, G.A. (1999). The role of information services in Government libraries in a

democratic culture. In (NLA Compendium of paper presentations): Information for the sustenance of a democratic culture. Port-Harcourt, Nigeria: NLA

Useni, J. (1998:1). Role of Libraries and information Centres.

NLA Newsletter 10(1) pp1 